\title{
Forum
}

\section{Knowing the Land: A Review of Local Knowledge Revealed in Ranch Memoirs}

\author{
Corrine Noel Knapp ${ }^{1}$ and Maria Fernandez-Gimenez ${ }^{2}$
}

Authors are ${ }^{1}$ Graduate Student, Department of Forest, Rangeland and Watershed Stewardship, 1472 Campus Delivery, Colorado State University, Fort Collins, CO 80523-1472, USA; and ${ }^{2}$ Associate Professor, Department of Forest, Rangeland and Watershed Stewardship, Colorado State University, Fort Collins, CO 80523-1472, USA.

\begin{abstract}
Lack of long-term ecological monitoring presents a challenge for sustainable rangeland management in many areas of the western United States. Ranchers and other land managers have local knowledge gained from ongoing experience in specific places that could be useful for understanding ecological change and best management practices. Local knowledge is defined as knowledge gained by daily contact with the natural world and ecological processes. Unfortunately, little is known about ranchers' local knowledge, and few studies have systematically examined the types, depth, and validity of this knowledge. Ranch memoirs offer an unexplored entry into rancher knowledge acquisition, categories, and context. In this study, we coded and analyzed eighteen ranch memoirs from the western United States to investigate the specific types, depth, and quality of local land knowledge. We found that ranchers possess knowledge of both management and ecology, and that these knowledge realms are intertwined and often inseparable. In addition to learning from experience, social interactions are an important part of rancher education and create a shared knowledge culture. In most of the memoirs, ranchers revealed very little knowledge of long-term patterns of vegetation change. In all the memoirs reviewed, ranchers articulated a deep sense of responsibility and connectedness to the landscapes they manage and steward. This review of ranch memoirs provides a framework for future studies of local knowledge by identifying how ranchers gain their knowledge of the landscapes they manage, describing some of the distinctive types of knowledge that ranchers possess, and challenging conventional classifications of rancher knowledge.
\end{abstract}

\section{Resumen}

La carencia de monitoreos ecológicos de largo plazo presenta un desafío para el manejo sostenible de las tierras en muchas áreas del oeste de los Estados Unidos. Los rancheros y otros encargados de la tierra tienen conocimiento local ganado de la continua experiencia en lugares específicos que podrían ser útiles para entender el cambio ecológico y las mejores prácticas de manejo. El conocimiento local se define como conocimiento obtenido por el contacto diario con el mundo natural y los procesos ecológicos. Desafortunadamente, poco se sabe sobre el conocimiento local de los rancheros, y pocos estudios han examinado sistemáticamente los tipos, la profundidad, y la validez de este conocimiento. Las memorias de los ranchos ofrecen una entrada inexplorada en la adquisición, categorías, y contexto del conocimiento del ranchero. En este estudio, nosotros codificamos y analizamos dieciocho memorias de ranchos del oeste de los Estados Unidos para investigar los tipos específicos, la profundidad, y la calidad del conocimiento local de la tierra. Hemos encontrado que los rancheros poseen conocimiento de manejo y de ecología, y que estos campos del conocimiento están entrelazados y son a menudo inseparables. Además del aprendizaje por experiencia, las interacciones sociales son partes importantes de la educación del ranchero y crean una cultura de conocimiento compartido. En la mayoría de las memorias, los rancheros revelaron muy poco conocimiento de cambios a largo plazo en los patrones de vegetación. En todas las memorias revisadas, los rancheros expresaron un sentido profundo de responsabilidad y conexión con los paisajes que administran y conservan. Esta revisión de las memorias del rancho proporciona un marco para futuros estudios del conocimiento local al identificar la manera en que los rancheros ganan su conocimiento de los paisajes que administran, al describir algunos de los tipos distintivos de conocimiento que los rancheros poseen, y al desafiar clasificaciones convencionales del conocimiento de los rancheros.

Key Words: local knowledge, ranch memoirs, rangeland, sustainability

\section{INTRODUCTION}

The western United States has a long history of transients: trappers, explorers, miners, and most recently, oil and gas companies and second homeowners. Ranchers are one of the

Research was funded by the Colorado Agricultural Experiment Station.

Correspondence: Corrine Noel Knapp, Dept of Forest, Rangeland and Watershed Stewardship, 1472 Campus Delivery, Colorado State University, Fort Collins, CO 80523-1472, USA. Email: corrieknapp@yahoo.com

Manuscript received 8 August 2007; manuscript accepted 2 January 2008. few groups of settlers who have stayed and managed to make a living off the western range. Few livelihoods demand their practitioners to spend so much time in specific landscapes, in all types of weather, and at all times of the year. The intimate knowledge they gain through daily interaction with landscapes might hold clues for sustainable land use in the West. However, few published studies have attempted to document and assess the types of knowledge ranchers have, how knowledge is gained, and what this knowledge could contribute to land management. 
Ranch memoirs provide preliminary information regarding what and how ranchers understand the landscapes they manage, and identify themes and categories of rancher knowledge. This information could serve as a basis for future investigations of rancher knowledge using a wide range of sources including interviews, surveys, workshops, and participant observation.

Local knowledge has been defined as knowledge "integrally linked with the lives of people, always produced in dynamic interactions among humans and between humans and nature, and constantly changing" (Agrawal 1995a, p. 429). Although local knowledge has been investigated as it applies to development (Chambers 1983; Nygren 1999; Nadasdy 2003), few studies have systematically explored rancher knowledge, which could be a valuable source for constructing management models (Bestelmeyer et al. 2004; Briske et al. 2006), inspiring and informing ongoing research (Clark 1997), and understanding vegetation change over time (Butzer and Helgren 2005). Although there is little published research on rancher knowledge in the western United States (Rowan et al. 1994; Thompson 2002), ranch memoirs provide a window into the life, learning, and insight of people who make their livings from specific landscapes.

In this essay, we reviewed 18 memoirs written by ranchers from across the west. Our objective was to better understand the nature of ranchers' ecological knowledge and how it is acquired and applied to land management. This effort was the first phase in a larger project that also involves interviewing ranchers in particular landscapes to document their ecological knowledge, and triangulating interviews with historical and ecological data sources. We approached the memoirs with three hypotheses. We believed that ranchers would have more management knowledge than ecological knowledge based on their livelihood and profit motivations. We suggested that ranchers would gain most of their knowledge from experience, and we proposed that because of their ongoing interaction in specific landscapes, ranchers might understand local vegetation fluctuations and dynamics over time.

\section{METHODS}

Given the lack of existing research, ranch memoirs offered an untapped and accessible introduction into rancher knowledge. Our goal in this project was to explore the content and quality of ranchers' knowledge and the values embedded within this knowledge. Exploratory studies are typically nonrandom and provide context and insight for further research (Steinberg 2004). Although primarily undertaken for exploratory purposes, we started with some preliminary hypotheses (stated above) to guide our analysis.

In the social sciences, texts are considered a valid and important source of qualitative data about society (Riessman 1993; Silverman 1993; Warren and Karner 2005). Content analysis has been used in a range of fields including psychology (Garel et al. 2007), sociology (Kain 2007), and healthcare (Abraham et al. 2007), among others. One textual source is literature, and literary analysis has been used to bring insight to medicine (Arraez-Aybar 2006), speech analysis (Herman 2006), and the relationship between humanity and nature
(Wesling 2006). In the realm of public lands, analysis of texts can help to understand beliefs about policy and management of public lands (McBeth et al. 2005), and sources of conflict over public lands (Bengston and Fan 1999). Texts provide a realm of information that, although secondary to their original purposes, might lend insights to other disciplines. However, it is important to keep in mind the primary intent of the text in order that insights emanating from them can be put in context.

Although texts can be analyzed in a quantitative manner, qualitative analysis is more flexible and often is useful for studies with little prior research. Several hypotheses structured the development of a coding list prior to reading the texts. These introductory codes helped to focus the analysis and tie research questions directly to the data (Miles and Huberman 1984). In addition, we used systematic grounded theory to create open and ongoing codes related to rancher knowledge (Strauss and Corbin 1990). This method allows researchers to piece together patterns and themes of interest within the texts (Neuman 2003). Once coding was completed, we organized the codes in order to evaluate our original hypotheses and assess emergent themes.

The data for this project consisted of eighteen ranch memoirs that were chosen based on recommendations from Range Ecology professors at Colorado State University and searches of regional library materials. Memoirs are a type of literary text created to tell a story and should not be assessed as an unfiltered or entirely accurate reflection of actual events and observations. However, memoirs can be used to reflect general categories of knowledge and preliminary themes of interest within the ranching community. We selected memoirs that were written from personal ranching experience in the Rocky Mountain West. We also prioritized memoirs written within the last twenty years, because we were interested in tying this literary analysis to future interviews with ranchers. In addition, we selected memoirs that were readily available through local libraries or interlibrary loan. Our findings reflect these selection criteria. In the future it might be interesting to compare memoirs from different geographic regions or time periods to see the differences in knowledge among different groups of ranchers.

This paper is an exploration of the nature, content, and values associated with rancher knowledge. It is not meant to be a synthesis or analysis of what ranchers know about landscapes. Although a useful foundation for further analysis of rancher knowledge, this study has several limitations. First, the sample might not accurately reflect the ranching population as a whole. Ranchers who choose to write a memoir are often more educated and many have left ranching to pursue other livelihoods; therefore memoirs represent a narrow segment of the ranching community. Second, the sample might not reflect all of the knowledge that ranchers have accumulated. It is important to understand the context and purpose of texts when using them in analysis (Hodder 2000). Memoirs are stories, and every story is limited in what it can portray (Riessman 1993). Any revelation of knowledge embedded within these stories is likely a byproduct of the primary storytelling purpose. They should not be treated as reporting of actual events and observations, but as a creative work that, although not literal, could help to reveal broad knowledge categories and themes. Finally, the written word might not be adequate for conveying 
ranchers' relationships to the landscapes they occupy. Memoirs should be treated as cultural artifacts that are incomplete and perhaps not entirely reflective of the knowledge and culture of the entire community. Although limited, textual analysis can provide introductory insights into themes and categories of knowledge that could be further explored using alternative data sources (interviews, case studies, ethnographic studies, etc.).

\section{RESULTS}

In this section, we present results related to each of our original hypotheses and then two emergent findings revealed during the coding process.

\section{Integrated Knowledge: Managing on Nature's Terms}

Because their livelihoods demand ranchers to develop management knowledge, we hypothesized that ranchers would reveal more management knowledge than ecological knowledge in their memoirs. Based on this dichotomy, we started out by coding two categories: management knowledge and ecological knowledge. The category of management knowledge included specific actions and techniques related to management of landscapes for livestock production, and ecological knowledge included knowledge related to ecological processes and plant and wildlife species not directly related to management. As the coding process continued, it became clear that many knowledge claims didn't fit easily into either category. Studies of local knowledge have often commented on its hybrid nature (Agrawal 1995b; Robbins 2006). In the texts reviewed, practical management knowledge often bled seamlessly into knowledge of ecology and ecological processes and vice versa. Rancher knowledge must be understood within the context of active management and specific places.

Originally, we separated knowledge related to terrain and hydrology from management knowledge related to livestock movement or the utilization of forage. However, it proved impossible to separate knowledge of the physical terrain from knowledge of the most appropriate way to manage and move livestock within it. Knowledge of natural terrain helped Ivan Doig and his father know where to move their sheep when a midsummer storm ravaged their ranch (Doig 1978). Intimacy with a riparian corridor helped Gary Penley find the best hunting spots and also know the places that held water the latest in the season (Penley 1998). In Hamil's memoir, knowledge of river patterns and alluvial wash helped him know where to place his irrigated hay meadows (Hamil 1976). Knowledge of terrain and hydrology is not clearly either management or ecological knowledge.

It seemed reasonable that knowledge of wildlife should be a separate category than knowledge of domesticated animals, but there were many places where these types of knowledge overlapped: predator/prey, competition over forage supply, and overlap of habitats. In these situations, ecological knowledge is useful for informing management decisions. Although many of the authors stated their reticence to kill predators (Hasselstrom 1987; Aadland 1998), knowledge of predators is necessary in order to minimize stock losses. In the memoirs, ranchers showed that they were aware of animals that can lower the potential productivity of their land, including prairie dogs
(Hasselstrom 1987), rattlesnakes (Ackerman 1980), and Mormon crickets (Walker 2005). Ranchers were also aware of the preferred habitats of domestic and wild animals and how these habitats overlap (Blunt 2002). Many of the ranchers in these memoirs expressed the belief that good habitat for domestic animals also provides good habitat for wild animals (Hasselstrom 1987; Kittredge 1992). Regardless of their final assessment of wildlife, ranchers revealed an intimate knowledge of their presence, habitat, and behavior.

Ranchers' knowledge of weather patterns demonstrated knowledge of both management and ecology. Understanding cyclical weather patterns and variation helps managers plan seasonal tasks and work with nature's cycles. Work is determined by the season: fruit picking and canning in the summer (Hamil 1976), lambing and calving in the spring (Doig 1978; Ackerman 1980), off-ranch work in the slower months of the winter (Spragg 1999), and irrigating to coincide with the growth of grasses in order to ensure enough feed for the following winter (Brown 1967). In the west, drought is expected, and the long-term knowledge of weather patterns can help ranchers prepare for and adapt to drought. Continued observation of specific locations makes ranchers sensitive to yearly weather patterns and changes including the depth of watering ponds (Peavey 2001), the amount of dust on country roads (Hasselstrom 1987), and the appearance of annual grasses (Duncklee 1994). This knowledge also allows ranchers to plan for extreme weather by selling cattle before prices drop (Duncklee 1994), purchasing extra hay before prices rise (Carpenter 1984), and finding new creative sources of forage for livestock (Duncklee 1994). Ranchers have no control over weather, and so they must learn to work with and adapt to both cyclical patterns and sudden or unexpected weather events.

Although management and ecological knowledge are often thought of as separate kinds of knowledge, in practice they often enforce and inform one another. As Ackerman states, "the best cowboy, by necessity, is a jack of all trades" (Ackerman 1980, p. 39). Perhaps because most ranchers learn from a complex suite of experience, expertise, and book learning, they are continually redefining what they know and what works on their ranch. Brown remarks, "experience multiplied by knowledge of facts equals good judgment" (Brown 1967, p. 115). This judgment is dependent on both knowledge of facts and knowledge of how to apply those facts to specific situations. Ranching communities value "knowledge that has daily use" (Hasselstrom 1987, p. 105), because they depend upon it to run their operations.

\section{A Network of Knowing}

Our second hypothesis was that the primary source of knowledge relating to ranching would be experience with land and animals. As we read the memoirs, we found that although ranchers gain knowledge through direct experience, other important sources of knowledge are formal and informal teachers and the history and stories of places. These social and historical dimensions of knowledge acquisition are important for understanding the transmission of social norms, the importance of rural communities to the continuity of ranching knowledge, and the meaning of landscape to ranchers. 
Ranchers learn from their families (Kittredge 1992; Penley 1998; Spragg 1999), ranch hands (Hamil 1976; Spragg 1999), and the community of ranchers (Ackerman 1980; Penley 1998; Walker 2005). Due to isolated living, fathers and mothers are often the earliest teachers, providing role models to emulate (Penley 1998) and are important sources of information about variation of forage over time (Doig 1978), changes in wildlife populations (Doig 1978), and the skills it takes to "manage in the world" (Spragg 1999, p. 240). Growing up on a ranch provides various teachers within the ranching community. Hamil describes the ranch hands as being at the "center of the only action that seemed to count" (Hamil 1976, p. 86). This early admiration of hard workers helps to instill a strong work ethic in many of the memoir narrators. Spragg relates his admiration of a long-time ranch employee by reflecting, "I wonder if I will be as good with a chainsaw when I am an old man” (Spragg 1999, p. 26). After Brown's husband dies, she learns about sheep from a kind old sheepherder who she describes as never having "looked inside a book, but he had a remarkable fund of wisdom and good judgment upon which I drew heavily" (Brown 1967, p. 124). These family members and neighbors provide a community in which knowledge is generated and shared, and strong work ethics are cultivated.

New ranchers who do not come from a ranching background often seek out long-time ranchers to serve as mentors (Duncklee 1994), or are taken under the wing by neighbors (Allen 2001). In Ackermans' book, Al Mitchell feels it is an important responsibility to teach "a trade" to young and troubled youth (Ackerman 1980, p. 21). Mentors help newcomers to "see" the natural world and counter the "years of city life that dull the enthusiasm" (Peavey 2001, p. 13). Informal exchange of information not only helps to gain understanding, but also to solidify and maintain relationships (Duncklee 1994). The social context of ranching provides much of the education about ranching. Newcomers are forced to fit into hierarchies of labor (Hamil 1976) and learn important lessons in social dynamics in this manner. Perhaps one of the most important lessons learned from others is that "there is no right answer" (Allen 2001, p. 124). These interactions provide opportunities for newcomers to learn about ranching and also to build social capital, the norms and networks of reciprocity and relationships of trust that individuals rely on to "get by" and "get ahead" and which can help community members interact cooperatively and advance collective goals (Putnam 1993, 2000).

This transfer of knowledge can be formal, but it is often done through humor and teasing. Doig learned how to stand his own at the bar where he learned "how to put in sharp licks of my own" (Doig 1978, p. 60). Teasing has its rules as well, which are often difficult for outsiders to comprehend. Ackerman describes that the social role of teasing is clear, "so large and close-living is the ranch family, safety valves abound" (Ackerman 1980, p. 106). Many of the lessons that ranchers need to learn must come from experience. Spragg gains a valuable lesson in getting what you think you want when an old cowboy gives him the chewing tobacco he was longing for. After becoming sick, the man comes back and cares for him. Afterwards, Spragg describes the sense that he was "no longer a boy" (Spragg 1999, p. 6). Ranchers are not only sharing knowledge about how to do certain tasks, but about how to live in particular communities.

Stories are an important teacher about the correct way to live. Understanding the stories of her mother-in-law's early experience cooking food for the ranchmen helped Peavey to understand her own place within the community (Peavey 2001). Landscapes also hold tangible reminders, or stories of the past. A cowboy is described as "living in a sea of his trophies, and each accomplishment...stocks his confidence and self esteem" (Ackerman 1980, p. 133). Landscapes serve as physical reminders of events in the past and help ranchers to remember lessons learned about fire (Hasselstrom 1987), endurance (Spragg 1999), responsibility (Hamil 1976), and caring for wildlife (Duncklee 1994). This "storied landscape" connects community members, reinforces shared norms, and creates another level of place connection.

History also provides stories about what will, and won't, work in a certain place. For ranchers, the history of a place is embedded in the landforms and seasons of the place they manage. For long-time ranching families, the land and the work are often deeply identified with departed relatives. Doig speaks of the work connecting him to both his father and his grandfather, and beyond that blood to the original homeland of his people in Scotland (Doig 1978). A physical landscape is often the only remaining physical reminder and clue regarding how and why people lived the way they did (Kittredge 1992). There is the physical reminder of old land use that is found in the black soil of an old garden long laid fallow (Aadland 1998), the physical presence of old implements and tools (Hamil 1976), and the respect and awareness of early settlers lodged in the common practice of calling places by their original owner's name (Doig 1978; Hasselstrom 1987). Aadland puts it this way: "there is not a day when I do not look over my shoulder for their approval of the job I am doing and either joy in having lived up to the task or despair because I haven't' (Aadland 1998, p. 18). The land is not merely a place, but a set of physical reminders about how to live on the land.

This community of knowledge sharing is threatened by changes in the ranching community and loss of neighbors and older ranchers. Good help is becoming increasingly difficult to find, whether for shearers (Blunt 2002), horse handlers (Aadland 1998), or for intensive tasks such as haying (Aadland 1998). New neighbors are "not living here for the same reasons we are," states a rancher in Aadland's memoir, "they aren't here to make a living" (Aadland 1998, p. 225), and they want new roads, schools, and amenities (Hasselstrom 1987). As Peavey states, "the traditional keepers of the land are cleared away, bought out, and the landscape turns from quiet introspection to carnivalesque cacophony" (Peavey 2001, p. xiii). As the ranching community changes, the ability to share knowledge with others who are trying to make their living off the land decreases, as does the shared connection to landscape.

\section{The Difficulty of Seeing What is Close at Hand}

Ranchers are out on the land almost every day of the year, fixing fence in the summer or feeding in the winter. This daily interaction with a familiar place gives ranchers a potential intimacy with landscape change over time. When we began this review, we hypothesized that if vegetative composition changed 
or fluctuated in response to management or environmental stressors, ranchers would demonstrate knowledge of these changes. Our review found that most ranchers spoke very little about vegetation change. Within the memoirs reviewed, there was one mention of increased sagebrush (Aadland 1998), one mention of increased weeds (Peavey 2001), and several mentions of increased riparian tree cover (Brown 1967; Hamil 1976). In only one memoir was there a mention of soils and their associated vegetation (Ackerman 1980). Ranch memoirs, therefore, offered little insight into ranchers' perception of vegetation change over time.

\section{Emergent Finding-the Cycle of Stewardship}

Emergent findings were identified through open coding and analysis of common thematic patterns. The first emergent finding was that ranchers expressed an overwhelming dependence on ecological and human communities and a corresponding ethic of responsibility that carried over into the social fabric of the ranching community. The second was that ranchers were uniquely sensitive to natural cycles of life and death and their place within them. This knowledge and awareness of the embeddedness of human experience in the natural world has implications for understanding man's place within nature and what sustainability might mean on a local scale.

In ranch memoirs, ranchers speak of their dependence on the landscapes they manage. Ranchers reveal this dependence as they hope and pray for rain (Duncklee 1994), wish against killing frosts (Kittredge 1992), and feel at times as if they are gambling (Doig 1978). As Aadland states succinctly, "you do not own a ranch-it owns you" (Aadland 1998, p. 17). Hasselstrom takes it even farther, reflecting on the fact that "ranchers often speak as if they are the land, saying things like "that fire burned seventy-five acres of me"' (Hasselstrom 1987, p. 87). This identification with specific landscapes shows an intense awareness of both belonging to and being dependent on the land and its resources.

This sense of dependence creates an intense accompanying feeling of responsibility. Ranchers describe their commitment to protecting wildlife habitat (Hasselstrom 1987), thinking of the long-term health of the land (Allen 2001), and balancing human and natural needs (Peavey 2001). Ackerman quotes rancher Al Mitchell as saying "we are conservation...ours is a long-term investment and we have to care about healthy herds, enough water and good grazing land" (Ackerman 1980, p. 42). This relationship is reciprocal and ranchers believe that "we have to take care of the country or it don't take care of us" (Hasselstrom 1987, p. 92).

The sense of responsibility does not end with the land, but spills out into the greater community. The responsibility is first to dependent animals (Hamil 1976), whose "contentment was a measure of their own" (Blunt 2002, p. 39). Blunt describes the guilt she felt when she skipped her chore of caring for the chickens, "it was a small, small person who bellied up to the table while his livestock stood hungry" (Blunt 2002, p. 36). The sense of responsibility also takes in the inanimate resources of the ranch. Hasselstrom describes her father as "learning the virtue of wearing out a piece of machinery, fixing it himself, making do" (Hasselstrom 1987, p. 9). In addition, ranchers feel responsibility to the work itself. As Spragg learns as a young adult, it is important to do things the right way because "careless boys grow into careless men" (Spragg 1999, p. 20). Building a fence became a work of art for Penley's grandfather (Penley 1998), Kittredge describes his tasks as "managing perfection" (Kittredge 1992, p. 155), and people are admired for "doing things the right way, carefully, thoroughly, without cutting corners" (Ackerman 1980, p. 98).

This responsibility also encompasses taking care of neighbors (Brown 1967), educating newcomers (Peavey 2001), and making all possible purchases locally (Hasselstrom 1987). As Duncklee defines it, neighborliness is "helping and being helped with neither having the feeling of being beholden to the other" (Duncklee 1994, p. 36). This feeling of responsibility to one another is part of the fabric of traditional ranching communities. Thinking over a new resident who didn't help a stranded neighbor, Aadland says, "thinking of the unquestioning help neighbors have given to me and I to them, I hope the rancher down the road is not a portent of things to come" (Aadland 1998, p. 170).

\section{Emergent Finding-Embedded Lives}

Ranch memoirs demonstrate ranchers' awareness and acknowledgement of their role in the cycle of life. Birth and death are ever-present on a ranch. Ranch children are often early assistants in the difficult births of animals (Penley 1998), and often witness the slow decay of dead animals on the road or in the pastures (Spragg 1999). This early awareness of death can lead to childhood cruelties, "when we can kill emotionlesslyor worse, simply from curiosity, to see how the tiny mice prodded from their field nest are different, dead, from the tiny mice, alive, of an instant ago" (Doig 1978, p. 11). Ranch children also have to learn to deal with the hard truth of nature, such as the need to kill a pet bobcat that was eating the chickens (Penley 1998). Ranchers learn about the reality of the cycle of life and death at a very early age.

This proximity and participation in nature's cycles makes it difficult for ranchers to see themselves as outside of these processes. Brown describes how she felt an "integral though humble part in the great design of nature," which she believed came to "only those who live out of doors" (Brown 1967, p. 124). In almost every memoir there was a critical instance of the awareness of one's place in the food chain and one's complicity and role in this cycle. Doig remembers his fathers' story of a bear, and the "hundred times told, and always with that last lilt of wonder in his voice that he could have been both hunter and hunted" (Doig 1978, p. 271). Early experience with the death of a favorite horse helps Hasselstrom say, "Mother Nature has a tendency to demand that we become philosophical about such things" (Hasselstrom 1987, p. 127). Within the ranch memoirs, humans are depicted as being within and not apart from natural cycles.

\section{DISCUSSION}

Ranch memoirs provide preliminary insights into the way that ranchers interact with the landscapes they manage, how they gain knowledge and how they apply that knowledge in their management practices. In the following sections, we address 
each of our original hypotheses and emergent findings and what insights they might have for rangeland management, rural communities, and future investigations of rancher knowledge.

Analysis of ranch memoirs showed that management and ecological knowledge were part of a seamless knowledge base. The reviewed memoirs show that ranchers must work within natural systems and therefore gain understanding of the limits of those systems. Knowledge of environmental limitations is important to sustainable land management, especially as new land uses (ranchettes, oil and gas development) are increasing in rangelands and these newcomers possess less situated knowledge of landscapes and their limitations. This integrated knowledge also could be an asset for developing sustainable application of general management techniques. However, the lens of management may also distort understanding of ecological processes and knowledge networks, as discussed below, may keep ranchers from changing management due to social pressure.

This review demonstrated the social dimension of rancher knowledge. The context of knowledge acquisition and application is vital for understanding the resilience of rancher knowledge and the challenges in encouraging management practice change. Ranch memoirs show that landscapes are saturated with historical and social meanings for ranchers, creating a deep sense of connection to both places and management practices. Although this can be beneficial for land stewardship, it can also make ranchers resistant to change. Ranchers often admire and respect the family and community members that taught them specific management practices, and questioning those practices is often difficult. The importance of social context also implies that functioning rural communities are vital for the transmission and preservation of both rural knowledge and strong land and work ethics. As ranching communities face demographic changes and associated landscape fragmentation, they can lose individuals who promote integrative thinking, encourage strong work ethics, and supply social capital that binds and sustains rural communities.

Ranch memoirs are a poor source of information about what ranchers know regarding vegetation change over time. This simply might be because there is no change occurring in these systems. It also might be due to the fact that people have a difficult time perceiving incremental changes in landscapes they manage daily. Additionally, it might be that memoirs are not the appropriate source of this knowledge. In future research, we plan to conduct both structured and open-ended field interviews with ranchers to discuss their knowledge of vegetation change. Ranchers are in daily contact with landscapes, and therefore much of their knowledge is tacit in nature (Fazey et al. 2006). Interviewing on specific landscapes might provide a better source of information about ranchers' knowledge of vegetation dynamics over time.

Ranch memoirs consistently demonstrated that ranchers feel dependent on and responsible to the landscapes they manage. This stewardship ethic is important to understand when working with ranchers to improve land management. Often it might be definitions of terms or incorrect assumptions rather than land ethics that cause conflict between land managers and ranchers. In addition to stewarding landscapes, ranchers also often steward relationships with neighbors and rural communities. This ethic suggests that the loss of viable ranches has the potential to create insularity and instability in small rural communities.

Ranchers do not share the common perception that humans are detached from nature. They see the human role as embedded within natural systems. Ranchers live with the consequences of management practices on land health. This potential awareness of management repercussions is important to understanding sustainability in a world that is increasingly disconnected due to globalization and consumerism. The tangible results of management decisions surround the rancher. Externalizing costs is difficult to do on a ranch scale, and therefore, the ranch provides a relatively closed loop for understanding sustainable practices. The embedded nature of rancher knowledge might make it hard to apply broadly, but might also make this knowledge vital for understanding what sustainability means at a ranch level.

Research regarding rancher knowledge is slim, and we used this review as a way to broadly understand and describe rancher knowledge. We hope that the insights gained in this review of rancher memoirs might stimulate further questions and research into rancher knowledge using other data sources. Qualitative coding was used because single-word tracking would have limited the analysis and tracking of concepts would have been difficult to interpret in a quantitative manner. In the future, it might be interesting to design a more quantitative textual analysis (Roberts 1997). Future research could also entail comparing historical and current memoirs, memoirs written by outsiders and insiders, or memoirs written by those who are still ranching with those who have left the ranch. In addition, research is needed to understand how to elicit knowledge of vegetation change over time, and what ranchers know about long-term vegetation change. This review of ranch memoirs serves as an entry and introduction into the field of rancher knowledge. In the next stage of our research, we plan to utilize the insights gained in this review to conduct on-site interviews with ranchers within a single watershed in northwest Colorado and triangulate their knowledge with a review of historical and ecological data.

\section{IMPLICATIONS}

While looking at each memoir through the lens of knowledge claims, it became apparent that there is no single "rancher knowledge"; rather, knowledge depends upon an individual's interests, background, experience, and learning. Although all ranchers have some knowledge based on their particular contexts, not all of the knowledge will be equally valid, useful, or pertinent. The heterogeneity of knowledge is important to understand when making any claims regarding rancher, or local, knowledge.

This study has identified several traits of rancher knowledge, including how it is acquired and conceptualized, and also what it can tell us about ranchers' relationships to landscapes. As ranching communities are threatened by rising land values, alternative land uses, and global competition, it is important to understand the strengths and weaknesses, and the potential applications of local knowledge. Rancher knowledge can provide understanding of best practices and application in specific places, but it also can be limited in scope and 
transferability. Rancher knowledge can inspire or inform scientific research, but it can also be maladaptive to change. Understanding both what, and also how, ranchers know can help provide a context for rancher beliefs and behaviors.

Most importantly, perhaps, rancher knowledge provides an understanding of what it is to live an embedded life in a particular landscape. Sustainability is not an ambiguous concept for ranchers, but a reality perceived in forage availability, soil stability, invasion of noxious weeds, and the continued ability to make a living off a particular landscape. If the goal of range management is to "provide for the needs of the present without compromising the ability of future generations to meet their own needs" (Brundtland Commission 1987), we might need to give greater consideration to the embedded knowledge that ranchers possess. We hope that this review will provide background and encouragement for future studies of rancher knowledge that will utilize multiple data sources to gain a more rigorous understanding of ranchers' local knowledge.

\section{LITERATURE CITED}

Abraham, C., L. Southby, S. Quandte, B. Krahe, and W. Van Der Sluiss. 2007. What's in a leaflet? Identifying research-based persuasive messages in European alcohol-education leaflets. Psychology \& Health 22:31-60.

Agrawal, A. 1995a. Dismantling the divide between indigenous and scientific knowledge. Development and Change 26:413-439.

Agrawal, A. 1995b. Indigenous and scientific knowledge. Indigenous Knowledge and Development Monitor 8:3-5.

Arraez-Aybar, L. A. 2006. Anatomy in the pages of Don Quixote. Interciencia 31:690-694.

Bengston, D. N., and D. P. Fan. 1999. Conflict over natural resource management: a social indicator based on analysis of online news media text. Society and Natural Resources 12:493-500.

Bestelmeyer, B. T., J. E. Herrick, J. R. Brown, D. A. Trujillo, and K. M. HAVSTAD. 2004. Land management in the American southwest: a state and transition approach to ecosystem complexity. Environmental Management 34:38-51.

Briske, D. D., S. D. Fuhlendorf, and F. E. Smeins. 2006. A unified framework for assessment and application of ecological thresholds. Rangeland Ecology \& Management 59:225-236.

Bruntland Commission. 1987. Our common future. Oxford, United Kingdom: Oxford University Press. $400 \mathrm{p}$.

Butzer, K. W., and D. M. Helgren. 2005. Livestock, land cover and environmental history: the tablelands of New South Wales, Australia. Annals of the Association of American Geographers 95:80-111.

Chambers, R. 1983. Rural development: putting the last first. London, United Kingdom: Longman. $246 \mathrm{p}$.

CLARK, J. 1997. Local knowledge and the precarious extension of social networks. Sociologia Ruralis 37:38-60.

Fazey, I., K. Proust, B. Newell, B. Johnson, and J. Fazey. 2006. Eliciting the implicit knowledge and perceptions of on-ground conservation managers of the macquarie marshes. Ecology and Society 11:25. Available at: http:// www.ecologyandsociety.org/. Accessed 15 July 2007.

Garel, M., M. Dardennes, and B. Blondel. 2007. Mother's psychological distress one year after very preterm childbirth. Child Care Health and Development 33:137-143.

Herman, D. 2006. Dialogue in a discourse context: science of talk in fictional narrative. Narrative Inquiry 16:75-84.

HodDER, I. 2000. The interpretation of documents and material culture. In: N. K. Denzin and Y. S. Lincoln [EDS.]. Handbook of qualitative research. Thousand Oaks, CA, USA: Sage Publications. p. 703-717.
KaIN, E. L. 2007. The sociology major at institutes of higher education. Teaching Sociology 35:31-47.

McBeth, M. K., E. A. Shanahan, and M. D. Jones. 2005. The science of storytelling: measuring policy beliefs in greater Yellowstone. Society and Natural Resources 18:413-429.

Mlles, M. B., and A. M. Huberman. 1984. Analysis during data collection. In: M. B. Miles and A. M. Huberman [EDS.]. Qualitative data analysis: a sourcebook of new methods. Beverly Hills, CA, USA: Sage Publications. $256 \mathrm{p}$.

NADASDY, P. 2003. Hunters and bureaucrats. Vancouver, British Columbia, Canada: University of British Columbia Press. 312 p.

Neuman, W. L. 2003. Analyzing qualitative data. In: W. L. Neuman [ED.]. Social research methods: qualitative and quantitative approaches. Boston, MA, USA: Allyn and Bacon. 584 p.

Nygren, A. 1999. Local knowledge in the environment-development discourse. Critique of Anthropology 19:267-288.

Putnam, R. D. 1993. Making democracy work: civic traditions in modern Italy. Princeton, NJ, USA: Princeton University Press. 258 p.

Putnam, R. D. 2000. Bowling alone: the collapse and revival of American community. New York City, NY, USA: Simon and Schuster. 541 p.

Riessman, C. K. 1993. Narrative analysis. Newbury Park, CA, USA: Sage Publications. $78 \mathrm{p}$.

RoBiIns, P. 2006. The politics of barstool biology: environmental knowledge and power in greater northern Yellowstone. Geoforum 37:185-199.

RoBerTs, C. W. 1997. Text analysis for the social sciences: methods for drawing statistical inferences from texts and transcripts. Mahwah, NJ, USA: Erlbaum. $316 \mathrm{p}$.

Rowan, R. C., H. W. Ladewig, and L. D. White. 1994. Perceptions vs. recommendations: a rangeland decision-making dilemma. Journal of Range Management 47:344-348.

Silverman, D. 1993. Texts. In: D. Silverman [ED.]. Interpreting qualitative data: methods for analyzing talk, text and interaction. London, United Kingdom: Sage Publications. p. 59-90.

SteINBERG, D. M. 2004. The social work students' research handbook. New York, NY, USA: Haworth Social Work Practice Press. $171 \mathrm{p}$.

Strauss, A., And J. Corbin. 1990. Basics of qualitative research: Grounded theory procedures and techniques. Thousand Oaks, CA, USA: Sage Publications. $270 \mathrm{p}$.

Thompson, C. M. 2002. Ranchers, scientists and grass-roots development in the United States and Kenya. Environmental Values 11:303-326.

Warren, C., and T. X. Karner. 2005. The textual and the visual as qualitative data. In: C. Warren and T. X. Karner [EDS.]. Discovering qualitative methods: field research, interviews and analysis. Los Angeles, CA, USA: Roxbury Publishing Company. 294 p.

WeSLING, L. 2006. Darwin in arcadia: brute being and the human animal dance from Gilgamesh to Virginia Woolf. Anglia-Zeitschrift Fur Englische Philologie 124:11-43.

\section{APPENDIX RANCH MEMOIRS INCLUDED IN REVIEW}

AadLand, D. 1998. Sketches from the ranch. Guilford, CT, USA: The Lyons Press. $259 \mathrm{p}$.

ACKERMAN, D. 1980. Twilight of the tenderfoot: a western memoir. Golden, CO, USA: Fulcrum Press. $208 \mathrm{p}$

AlLeN, P. 2001. A geography of saints. Cambridge, MA, USA: Zoland Books. $263 p$.

BLunt, J. 2002. Breaking clean. New York, NY, USA: Alfred A. Knopf. 303 p.

Brown, M. D. 1967. Shepherdess of Elk River Valley. Denver, CO, USA: Golden Bell Press. $127 \mathrm{p}$.

Carpenter, F. 1984. Confessions of a maverick. Denver, CO, USA: State Historical Society of Colorado. $216 \mathrm{p}$.

DoIG, I. 1978. This house of sky. New York, NY, USA: Harcourt Brace Jovanovich. $314 \mathrm{p}$. 
DunckleE, J. 1994. Good years for the buzzards. Tuscon, AZ, USA: The University of Arizona Press. $165 \mathrm{p}$.

ERLICH, G. 1985. The solace of open spaces. New York, NY, USA: Viking. $131 \mathrm{p}$. HamIL, H. 1976. Colorado without mountains. Kansas City, MO, USA: The Lowell Press. 283 p.

Hasselstrom, L. M. 1987. Going over east. Golden, CO, USA: Fulcrum, Inc. 206 p.

Kittredge, W. 1992. Hole in the sky. New York, NY, USA: Alfred A. Knopf. 238 p.

Miller, I. 1989. The Ozark Clan of Elkhead Creek. Yellow Cat Flats, UT, USA: Yellow Cat Publishing. 322 p.
Moody, R. 1991. Little britches: father and I were ranchers. New York, NY, USA: Norton. $261 \mathrm{p}$.

PeAveY, D. J. 2001. Bitterbrush country: living on the edge of the land. Golden, CO, USA: Fulcrum Press. 239 p.

Penley, G. 1998. Rivers of wind. Palmer Lake, CO, USA: Filter Press. 219 p.

SPRAGG, M. 1999. Where rivers change direction. Salt Lake City, UT, USA: University of Utah Press. 267 p.

Walker, Q. M. 2005. The Mantle ranch. Boulder, CO, USA: Fred Pruett Books. $277 p$. 